\title{
Front Matter: Volume 8843
}

, "Front Matter: Volume 8843," Proc. SPIE 8843, Laser Beam Shaping XIV, 884301 (18 October 2013); doi: 10.1117/12.2047162

SPIE Event: SPIE Optical Engineering + Applications, 2013, San Diego, California, SPIE. United States 


\section{PROCEEDINGS OF SPIE}

\section{Laser Beam Shaping XIV}

Andrew Forbes

Todd E. Lizotte

Editors

26 August 2013

San Diego, California, United States

Sponsored and Published by

SPIE 
The papers included in this volume were part of the technical conference cited on the cover and title page. Papers were selected and subject to review by the editors and conference program committee. Some conference presentations may not be available for publication. The papers published in these proceedings reflect the work and thoughts of the authors and are published herein as submitted. The publisher is not responsible for the validity of the information or for any outcomes resulting from reliance thereon.

Please use the following format to cite material from this book:

Author(s), "Title of Paper," in Laser Beam Shaping XIV, edited by Andrew Forbes, Todd E. Lizotte, Proceedings of SPIE Vol. 8843 (SPIE, Bellingham, WA, 2013) Article CID Number.

ISSN: 0277-786X

ISBN: 9780819496935

Published by

SPIE

P.O. Box 10, Bellingham, Washington 98227-0010 USA

Telephone +1 3606763290 (Pacific Time) · Fax +1 3606471445

SPIE.org

Copyright (C) 2013, Society of Photo-Optical Instrumentation Engineers.

Copying of material in this book for internal or personal use, or for the internal or personal use of specific clients, beyond the fair use provisions granted by the U.S. Copyright Law is authorized by SPIE subject to payment of copying fees. The Transactional Reporting Service base fee for this volume is $\$ 18.00$ per article (or portion thereof), which should be paid directly to the Copyright Clearance Center (CCC), 222 Rosewood Drive, Danvers, MA 01923. Payment may also be made electronically through $\mathrm{CCC}$ Online at copyright.com. Other copying for republication, resale, advertising or promotion, or any form of systematic or multiple reproduction of any material in this book is prohibited except with permission in writing from the publisher. The CCC fee code is $0277-786 \mathrm{X} / 13 / \$ 18.00$.

Printed in the United States of America.

Publication of record for individual papers is online in the SPIE Digital Library.

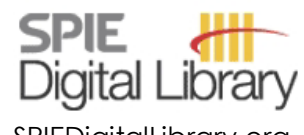

SPIEDigitalLibrary.org

Paper Numbering: Proceedings of SPIE follow an e-First publication model, with papers published first online and then in print and on CD-ROM. Papers are published as they are submitted and meet publication criteria. A unique, consistent, permanent citation identifier (CID) number is assigned to each article at the time of the first publication. Utilization of CIDs allows articles to be fully citable as soon as they are published online, and connects the same identifier to all online, print, and electronic versions of the publication. SPIE uses a six-digit CID article numbering system in which:

- The first four digits correspond to the SPIE volume number.

- The last two digits indicate publication order within the volume using a Base 36 numbering

system employing both numerals and letters. These two-number sets start with 00, 01, 02, 03, 04, $05,06,07,08,09,0 A, 0 B \ldots$. OZ, followed by 10-1Z, 20-2Z, etc.

The CID Number appears on each page of the manuscript. The complete citation is used on the first page, and an abbreviated version on subsequent pages. Numbers in the index correspond to the last two digits of the six-digit CID Number. 


\section{Contents}

vii Conference Committee
ix Introduction

\section{SESSION 1 VORTEX BEAMS}

884302 Determination of angular momentum content in partially coherent beams through cross correlation measurements [8843-1]

A. Yepiz Escalante, B. Perez-Garcia, R. I. Hernandez-Aranda, Tecnológico de Monterrey (Mexico); G. A. Swartzlander Jr., Rochester Institute of Technology (United States)

884303 Measuring topological charge using Stokes parameters [8843-2]

B. Perez-Garcia, Tecnológico de Monterrey (Mexico); D. Lopez-Mago, Tecnológico de Monterrey (Mexico) and ETH Zurich (Switzerland); A. Yepiz Escalante,

R. I. Hernandez-Aranda, J. C. Gutiérrez-Vega, Tecnológico de Monterrey (Mexico)

884304 Optical fields with tunable transverse intensity fluxes arranged over a semi-circle [8843-3]

A. Ruelas, M. G. Jurado-Taracena, J. C. Gutiérrez-Vega, Tecnológico de Monterrey

(Mexico)

884305 Generating and analyzing non-diffracting vector vortex beams [8843-4]

Y. Li, North Carolina State Univ. (United States); A. Dudley, T. Mhlanga, CSIR National Laser Ctr. (South Africa); M. J. Escuti, North Carolina State Univ. (United States); A. Forbes, CSIR National Laser Ctr. (South Africa)

884306 Techniques to sort Bessel beams (Invited Paper) [8843-5]

A. Dudley, CSIR National Laser Ctr. (South Africa); T. Mhlanga, CSIR National Laser Ctr. (South Africa) and Stellenbosch Univ. (South Africa); A. McDonald, F. S. Roux, CSIR National Laser Ctr. (South Africa); M. Lavery, M. Padgett, Univ. of Glasgow (United Kingdom); A. Forbes, CSIR National Laser Ctr. (South Africa), Stellenbosch Univ. (South Africa), and Univ. of KwaZulu-Natal (South Africa)

\section{SESSION 2 THEORY AND TECHNIQUES}

884307 Beam shaping by volume phase structures in photo-thermo-refractive glass (Invited Paper) [8843-6]

M. SeGall, I. Divliansky, D. Ott, J. Lumeau, S. Mokhov, B. Zeldovich, L. B. Glebov, CREOL, The College of Optics and Photonics, Univ. of Central Florida (United States)

884308 The effect of spatial light modulator (SLM) dependent dispersion on spatial beam shaping [8843-7]

D.-M. Spangenberg, Stellenbosch Univ. (South Africa); A. Dudley, CSIR National Laser Ctr. (South Africa); P. Neethling, Stellenbosch Univ. (South Africa); A. Forbes, CSIR National Laser Ctr. (South Africa); E. Rohwer, Stellenbosch Univ. (South Africa) 
$88430 \mathrm{~A}$ Steerable diffraction limited line illumination system using deformable mirror [8843-9] K. Taniguchi, Hitachi High Technologies Corp. (Japan); D. W. Kim, College of Optical Sciences, The Univ. of Arizona (United States); K. Shimura, Hitachi High Technologies Corp. (Japan); J. H. Burge, College of Optical Sciences, The Univ. of Arizona (United States)

\section{SESSION 3 APPLICATIONS I}

8843 OC Beam shaping to generate uniform laser light sheet and linear laser spots [8843-12]

A. Laskin, V. Laskin, AdlOptica GmbH (Germany)

8843 OD Active optical system for laser structuring of 3D surfaces by remelting [8843-13]

O. Pütsch, A. Temmler, RWTH Aachen Univ. (Germany); J. Stollenwerk, RWTH Aachen Univ. (Germany) and Fraunhofer Institute for Lasertechnology (Germany); E. Willenborg, Fraunhofer Institute for Lasertechnology (Germany); P. Loosen, RWTH Aachen Univ. (Germany) and Fraunhofer Institute for Lasertechnology (Germany)

8843 OE Dynamic holography for extended object beam shaping [8843-14] A. T. Watnik, P. S. Lebow, U.S. Naval Research Lab. (United States)

SESSION 4 APPLICATIONS II

8843 OG Beam shaping unit for micromachining (Invited Paper) [8843-16] A. Laskin, AdlOptica GmbH (Germany); N. Šiaulys, G. Šlekys, Altechna (Lithuania); V. Laskin, AdlOptica GmbH (Germany)

$8843 \mathrm{OH}$ Beam shaping diffuser based fiber injection for increasing stability of industrial robotic laser applications [8843-17]

T. E. Lizotte, Hitachi Via Mechanics (USA), Inc. (United States); F. M. Dickey, FMD Consulting LLC (United States)

8843 0J A novel interpretation of the integrator [8843-29]

A. Stockham, LightWorks Optical Systems (United States)

POSTER SESSION

8843 OM Differential time delay line network for optical controlled beam forming [8843-22] J. Sun, L. Wang, P. Hou, L. Liu, Y. Zhi, Y. Zhou, Shanghai Institute of Optics and Fine Mechanics (China)

$88430 \mathrm{~N}$ Formation and propagation of Bessel beams: practical considerations [8843-23] M. Soskind, R. Soskind, Rutgers, The State Univ. of New Jersey (United States); Y. G. Soskind, DHPC Technologies (United States)

884300 Producing Bessel beams based on incoherent superposition of laser fields [8843-24] M. Soskind, R. Soskind, Rutgers, The State Univ. of New Jersey (United States); Y. G. Soskind, DHPC Technologies (United States) 
8843 OP Diffracted fields by slit-shape transmittance curves [8843-25]

J. Silva Barranco, G. Martínez Niconoff, Instituto Nacional de Astrofísica, Óptica y Electrónica (Mexico)

$88430 Q$ Creation of flattop light field through tightly focusing of cylindrical vector beams [8843-26] C. You, H. Yi, W. Wang, W. Lv, M. Yun, Qingdao Univ. (China)

8843 OR Optical tweezers formed by pure phase pupil filter [8843-27]

W. Lv, C. You, M. Wang, M. Yun, Qingdao Univ. (China)

8843 OS Faster learning algorithm convergence utilizing a combined time-frequency representation as basis [8843-28]

A. J. Hendriks, H. Uys, CSIR National Laser Ctr. (South Africa); A. du Plessis, C. Steenkamp, Stellenbosch Univ. (South Africa)

Author Index 
Proc. of SPIE Vol. $8843884301-6$

Downloaded From: https://www.spiedigitallibrary.org/conference-proceedings-of-spie on 26 Apr 2023 Terms of Use: https://www.spiedigitallibrary.org/terms-of-use 


\section{Conference Committee}

Program Track Chairs

José Sasián, College of Optical Sciences, The University of Arizona (United States)

R. John Koshel, Photon Engineering LLC (United States) and College of Optical Sciences, The University of Arizona (United States)

\section{Conference Chairs}

Andrew Forbes, CSIR National Laser Center (South Africa) and University of KwaZulu-Natal (South Africa)

Todd E. Lizotte, Hitachi Via Mechanics (USA), Inc. (United States)

Conference Program Committee

Daniel M. Brown, Optosensors Technology, Inc. (United States)

Fred M. Dickey, FMD Consulting LLC (United States)

Michael Duparré, Friedrich-Schiller-Universität Jena (Germany)

Julio Cesar Gutiérrez-Vega, Tecnológico de Monterrey (Mexico)

Alexander V. Laskin, AdlOptica Optical Systems GmbH (Germany)

Alexis V. Kudryashov, Active Optics Night N Ltd. (Russian Federation)

Carlos López-Mariscal, U.S. Naval Research Laboratory (United States)

John Rauseo, Nalux Company, Ltd. (United States)

José Sasián, College of Optical Sciences, The University of Arizona (United States)

David L. Shealy, The University of Alabama at Birmingham (United States)

Yakov G. Soskind, DHPC Technologies (United States)

Session Chairs

1 Vortex Beams

Andrew Forbes, CSIR National Laser Center (South Africa) and University of KwaZulu-Natal (South Africa)

2 Theory and Techniques

Fred M. Dickey, FMD Consulting LLC (United States)

3 Applications I

Todd E. Lizotte, Hitachi Via Mechanics (USA), Inc. (United States)

4 Applications II

Yakov G. Soskind, DHPC Technologies (United States) 
Proc. of SPIE Vol. $8843884301-8$

Downloaded From: https://www.spiedigitallibrary.org/conference-proceedings-of-spie on 26 Apr 2023 Terms of Use: https://www.spiedigitallibrary.org/terms-of-use 


\section{Introduction}

As conference chairs we look forward to read the abstracts submitted and the final papers brought forward each year.

This year was no different; the diversity of papers demonstrates the critical role of laser beam shaping techniques. The papers provide glimpses into what could be the next leap in laser beam shaping; through further understanding and refinement of theory or how applications have been adopted into real life industrial laser tools.

The chairs are grateful to everyone who participated in this year's conference and thank you for sharing your work.

We look forward to celebrating a milestone in the conferences history at Laser Beam Shaping XV in 2014.

Andrew Forbes

Todd E. Lizotte 
Proc. of SPIE Vol. $8843884301-10$

Downloaded From: https://www.spiedigitallibrary.org/conference-proceedings-of-spie on 26 Apr 2023 Terms of Use: https://www.spiedigitallibrary.org/terms-of-use 